\title{
Hymenochaete carpatica from Częstochowa Upland (S Poland)
}

\author{
LOTHAR KRIEGLSTEINER ${ }^{1}$ and MARIA LAWR YNOWICZ ${ }^{2}$ \\ 'Institut für Botanik, Universitat Regensburg Postfach. 101042, D-93040 Rcgensburg \\ Present address: Beethovenstr. 1, D-73568 Durlangen, I.krieglsteiner@t-oaline.de \\ 2 Department of Algology and Mycology, University of Lódz \\ Banacha 12/16, PL-90-237 Lodi, miklaw@biol,unilodz.pl
}

Krieglsteiner L., Lawrynowicz M : Hymenochaete carpatica from Czesstochowa Upiand (S Poland). Acta Mycol. 38 (1/2): 27-30, 2003.

Hymenochacte carpatica has been found in 1994 in Częstochowa Upland, "Parkowe" nature reserve, in Wiercica river valley situated on calcareous area, $290-310 \mathrm{~m}$ above sea level, on fissured bark of Acer pseudoplaranus. This contribution corresponds to the paper by Chle bicki (2003) who has recently discovered scveral localities of $H$. carpatica in Sudetes and Carpathitans. Both papers present a set of sites of $H$. capatica reported hitherto from Poland, and contribute to the knowledge on its distribution in Europc.

Key words: Hymenochaete carpatica, ccology, distribution

\section{INTRODUCTION}

Hymenochnete carpatica (Pilát 1930) was originally described from Low Carpathians in Slovakia. For the next 58 years it had been completely overlooked in Europe (Baici and Léger 1988). It has a very special ecology because it grows only on the bark of Acer pseudoplatanus L., mainly on the inner side of the pieces still attached to living trees. Only in mountain areas where there are very moist air conditions it is able to grow also on the outer side of the bark and is more likely to be found. G. J. Krieglsteiner (1994) presented morphology, chorology, ecology and taxonomy of $H$. carpatica. He considers $H$. carpatica as well-defined and -delimited fungus, fairly common, at least regionally. $H$. carpatica is macroscopically similar to the other brown-colored resupinate species $H$. corrugata (Fr.) Lév., but differs microscopically in having longer setae, larger basidia and larger spores. According to the above author $H$. carpatica is widespread in Central Europe and locally common in mountain regions of Southern Germany, Eastern France (Vosges), Switzerland (Baici and Léger 1988) and particularly in Austria. He also discusses the question that although there are no data on $H$. carpatica in Eastern Europe, finding it there is highly probablc. 
In 1994, during the excursion to the Częstochowa Upland in the frame of mycological exchange programme between the universities of Regensburg and $\ell$ ódź, a rich collection of Asco- and Basidiomycota as well as Myxomycetes has been made by the authors. Among the collected species Hymenochaete carpatica was also distinguished. The material is successively completed and prepared for publication.

The article by Chlebicki (2003) containing excellent data concerning taxonomy, mode of life and ecology of $H$. carpatica found in Sudetes and Carpathians stimulated the authors to give a short note about its occurrence in the Czestochowa Upland. More detailed claboration of $H$. carpatica and some other species collected will be published separately.

\section{AREA OF INVESTIGATIONS}

The nature reserve "Parkowe" (Fig. 1) comprises elevations built of High Jurassic rocks emerging from under diluvial sands. It is a good cxample of phytosociological and forest conditions, characteristic of the whole region of the Czesstochowa Jurassic system. Oak-hornbeam forest (Tilio-Carpinetum), confined as a rule to the lowest parts of the area, is characterized by great fertility and optimum humidity (Celiński and Wika 1975). Acer pseudoplatanus is fairly widespread in the area of the reserve.

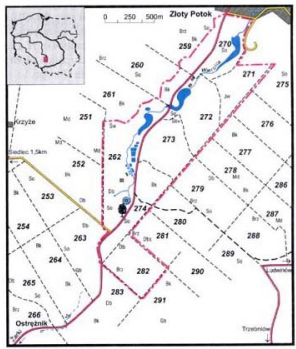

Fig 1. Locality - "Parkone" nature reserve ( $\mathrm{H}$ erej ni a k 2002).

4 Sire of collected Hymenochaese carpatics

3. Springs of Wiercica river "Zrodla Zygmunta"

- Bisder of the nature reserve 
The area has been the object of mycological investigations for many years (Eawrynowicz 1989, 1990). Altogether 356 species of macrofungi, among them Hymenochacte rubiginosa (Dicks.: Fr.) Lév., have been reported from the "Parkowe" nature reserve (Adamczyk 1996).

\section{HYMENOCHAETE CARPATICA IN POLAND}

H. carpatica has been reported recently from three regions in Poland: Sudetes and Carpatians (Chlebicki 2003), and Częstochowa Upland. The first collection in the Czestochowa Upland in the "Parkowe" nature reserve, forest section 262, has been made on July 15, 1994, in the site indicated on Figure 1, but further random observations reveal its common occurrence on Acer pseudoplatarus growing along the Wiercica river, especially a round its spring called "Źródla Zygmunta". The clcvation of the valley is $290-310 \mathrm{~m}$ a.s. 1 . The fungus grew exclusively on the inner surface of loosing bark fragments on old living trees of $A$. pseudoplatanus and was observed all over the year:

H. carpatica was previously regarded as a mountain species. According to some authors it can grow in a broad range of elevations (e.g. G. J. Krieglsteiner (1994): 250-1700 m a.s.1.; Tomšovský (2001): 290-1220 m a. s. l.).

Chlebicki (2003) collected $H$. carpatica at an altitude of $460-1000 \mathrm{~m}$ a.s.l. but in his opinion the fungus can grow both in the lowlands and in the mountains. The site in the Częstochowa Upland of $290-310 \mathrm{~m}$ a. s. 1 . is an example of the occurrence of this fungus at the lower elevation. L. Kriegls teine r (1999:382) collected it in Germany as low as $180 \mathrm{~m}$ a.s.l. Thus it can be expected in the whole range of natural occurrence of Acer pseudoplatanus. We hope this note will stimulate further searching.

The specimens collected in the Czestochowa Upland have becn deposited in the Herbarium Universitatis Lodziensis (LOD), Poland, and in the "Fungarium Krieglsteiner" (PH Schwäbisch Gmünd), Germany.

Acknowledgements: The authors thank to Professor A. Bresinsky (Regensburg) for coxdination of the mycological exchange programme on the German side. The publieation was prepared with financial support of the University of kódz. The authors are indebted to Professor A. Chlebicki who kindly accepled a sugestion to publish both papers in the sarne volume.

\section{REFERENCES}

Adamczyk J. 1996. Les champignons supéricurs des hêtrais du nord du plateau de Częstochowa. Lejeunia, Nouvelle sèrie 150: 1.83.

Baict A., Léger J. C. 1988. Hymenochaete carpatica (Pilát 1930) collected in Switzerland, Mycol. Helvetica 3(1): 89-98.

Celiński F., Wika S. 1978. Próba nowego spojrzenia na stosunki fitosocjologiczne rezerwatu "Parkowe"w Zlotym Potoku koło Częstochowy - A new Look at Phytosociological Conditions in the "Parkowe" Reservation in Zloty Potok ncar Czcstochowa. Fragm. Flor. et Geobot. 24 (2): 277-307.

Chlebicki A. 2003. Hymenochate carpatice, an inconspicuous fungus growing on chips of bark of Acer pseudoplatanus. Acta Mycol. 38 (1/2): 21-26.

Hereźniak J. 2002. Rezerwaty przyrody Ziemi Częstochowskiej. LOP, Częstochowa, $300 \mathrm{pp}$.

Krieglsteinef G. J. 1994. Hymenochaese carpatica Pilát 1930, die Bergahorn-Borstenscheibe, in Mitteleuropa. Beitr. Kenntur. Pilze Mitteleur. 9: 76-96. 
Kriezlsteiner L. 1999. Pilze in Naturraum Mainfränkische Platten und ihre Einbindung in dic

Vegetation. Regensb. Mykol. Schr. 9. 1: 1-464.

Ławrynowicz M. 1989. Chorology of the European hypozeous Asconzicter 1. Elaphontycetales. Acta

Mycol. 25 (1): 3-41.

Eawry nowicz M. 1990, Coorology of the European hypogeous Ascomyceies IL. Tubcrdes. Acta Mycol. $26(1) \div 7-75$.

Pilát A. 1930. Monographie der europalischen Steraceen. Hedwigia 70: 10-132.

Torn jovsk $\dot{y}$ M. 2001. Remerks on the distribution of Hymenocheete camatiea in Central and Eastern Europe. Crech Mycol. 53 (2): 141-148.

Hymenochaete carpatica na Wyżynie Cz̨̧stochowskiej

\section{Sireszezenic}

Grzyb Hymenochaete camatica został opisany przez Piláta (1930) ze Stowacji. Jest to gatunek rosnacy po wewnẹtrznej stronie huszczacych sį̨ platów kory jaworu Acer pseudoplatanus. Chociaż, jak wykazano, jest przynajmnicj regionalnic pospolity, przez 58 lat pozostawal niczauważony przez mikologów.

Dopiero Baici i Léger (1988) zwrócili uwagę na ten gatunek analizując materiały ziclnikowe oraz wykazując jego występowanic w wielu micjscach w Szwajcarii. G. J. Krieglsteiner (1994) opublikowat obszerne studium taksonomiczno-chorologiczne tego gatunku.

W lipcu 1994 roku w ramach realizacji programu współpracy miẹdzy uniwcrsytetami w Lodzi i Regensburgu autorzy niniejszej pracy prowadzili terenowe badania mikologiczne na Wyłynic Crçstochowskicj. Wśród bogatego materiału, który jest przedmiotem oddzielnego opracowywania, picrwszy autor zwrócit uwage na Hymenochaele carpatica, gatunek rozpoznany na korze jaworu w rezerwacie „Parkowe" kolo żrôdeł rzeki Wiercicy, znanych jako "Z Zódła Zygmunta" koło miejscowcsíci Złoty Potok. Obserwacjc prowadzone w kolejnych latach dostarccyly informacji o wystçpowaniu Hymenochaete carpatica na dalszych okazach jaworu rosnacych $w$ dolinie rzeki Wiercicy. Projcktowane sq szezegótowe badania nad rozmieszczeniem $\boldsymbol{H}$. carpatica na Wyżynie Częstochowskiej. Do podania informacji o odkryciu na Wyzynie Częstochowskiej $H$. carpatica skłonil autorow artykuł Chlebickiego (w tym tomie), kı́ry nie tylko znalazł ten gatunek w Sudetach i Tatrach ale stwierdzit jego pospolitość w nicktórych regionach, a także szczcgólowo opisał $\mathrm{i}$ zilustrowal ccchy morfologiczne owocników oraz sposób życia i rozwoju $H$. carpatica w warunkach konkurencji z innymi organizmami. Można oczekiwać, że podane w obu artykułach informacje zachęcq do poszukiwan tego gatunku również $\mathrm{w}$ innych regionach w zasięgu występowania Acer psetidoplaianus. 